WIDER Working Paper 2018/170

Economic inequality and subjective well-being across the world

Andrew E. Clark ${ }^{1}$ and Conchita D'Ambrosio ${ }^{2}$

December 2018 
Abstract: We here use repeated cross-section data from the Afrobarometer, Asianbarometer Latinobarometer, and Eurobarometer to analyse the variables that are correlated with both current and future evaluations of standards of living. These are related not only to an individual's own economic resources but also to the country distribution of resources. We consider resource comparisons (the gap in resources between richer and poorer individuals) and the normative evaluation of distribution (conditional on these gaps), given by the Gini coefficient. The 'typical' pattern of a negative effect of gaps on the better-off but a positive effect of gaps on the worse-off is found only in Europe: gaps for the better-off in Africa and Central and Latin America have no correlation with current life evaluations and are associated with more positive expectations of the future. Equally, there is no positive estimated coefficient for gaps to the worse-off in Asia. The Gini coefficient is negatively correlated with current life evaluation only in Asia, and is insignificant everywhere else. On the contrary, future life evaluations are more positive in more unequal countries in Africa and Central and Latin America. The relationship between the distribution of resources and measures of individual well-being over time is far from universal.

Keywords: barometers, Gini coefficient, inequality, living conditions, relative deprivation, WIID JEL classification: I31, I32, D60

Acknowledgements: We are very grateful to Anthony Lepinteur for excellent research assistance. Conchita D'Ambrosio gratefully acknowledges financial support from the Fonds National de la Recherche Luxembourg.

\footnotetext{
${ }^{1}$ Paris School of Economics - CNRS, Paris, France; ${ }^{2}$ Université du Luxembourg, Esch sur Alzette, Luxembourg; corresponding author: conchita.dambrosio@uni.lu
}

This study has been prepared within the UNU-WIDER project on 'Inequality in the Giants'.

Copyright (C) UNU-WIDER 2018

Information and requests: publications@wider.unu.edu

ISSN 1798-7237 ISBN 978-92-9256-612-8 https://doi.org/10.35188/UNU-WIDER/2018/612-8

Typescript prepared by Gary Smith.

The United Nations University World Institute for Development Economics Research provides economic analysis and policy advice with the aim of promoting sustainable and equitable development. The Institute began operations in 1985 in Helsinki, Finland, as the first research and training centre of the United Nations University. Today it is a unique blend of think tank, research institute, and UN agency — providing a range of services from policy advice to governments as well as freely available original research.

The Institute is funded through income from an endowment fund with additional contributions to its work programme from Finland, Sweden, and the United Kingdom as well as earmarked contributions for specific projects from a variety of donors.

Katajanokanlaituri 6 B, 00160 Helsinki, Finland

The views expressed in this paper are those of the author(s), and do not necessarily reflect the views of the Institute or the United Nations University, nor the programme/project donors. 
There is widespread consensus that economic inequality influences individual well-being through a number of different channels. Living in a society where the gap between the rich and the poor is wide has both economic and social consequences. As Van de Werfhorst and Salverda (2012) report in the introduction of the special issue they edited on the consequences of economic inequality, in unequal societies crime rates are higher, population health is worse, child bullying occurs more often, housing conditions are more disparate, social trust erodes, and political participation deteriorates. We refer the reader to the references therein and to the excellent discussion that appears in the articles making up this special issue for the details on these findings.

Our aim here is to contribute to this literature and focus on the study of the relationship between subjective evaluations of individual living conditions and economic inequality. We aim to explore empirically whether individuals' evaluations of their present and future living conditions are influenced by the level of economic inequality pertaining in their country of residence. We do so using data for 76 different countries across the world, observed at a number of different points in time between 1998 and 2015. We use all of the available Barometers data, which allows us to consider a spatial analysis of this relationship for different continents to see whether our findings are universal or whether they differ by region. To the best of our knowledge, our work here is the first to offer a complete global picture of how differences in control over economic resources are reflected in individuals' subjective evaluations of their living conditions, both current and future.

There has been an upsurge of interest in subjective measures of well-being, as complements to the more traditional income- or resource-based objective measures. For data reasons, this analysis has most often concentrated on OECD countries. However, more recent work has extended these analyses to developing countries. Some examples in this respect are presented by Akay and Martinsson (2011), Bookwalter and Dalenberg (2010), Lentz (2017), Clark and D'Ambrosio (2017), the contributions in the volume by Clark and Senik (2014), and the chapters in the recent World Happiness Reports that describe the analysis of Gallup well-being data covering every country in the world.

There are a number of reasons to expect a relationship between economic inequality and subjective well-being. Here we use the term economic inequality to refer to any disparities in the command over economic resources between individuals (i.e. there is economic inequality when individuals have different levels of command over resources). As opposed to many of the other variables that have been related to individual well-being, economic inequality does not exist at the individual level and is rather measured only at an aggregate, often societal, level. The key axiom in the measurement of inequality is the Pigou-Dalton principle of transfers, according to which inequality increases whenever there is a transfer of resources from a poorer to a richer individual. Even though economic inequality as such is not an individual-level concept, any distribution of economic resources will have individual-level effects due to the way it changes the individual's own access to economic resources and her standing with respect to those who are richer or poorer.

The theoretical framework we follow here was introduced in some of our previous work (Clark and D'Ambrosio 2015). We postulate that the effects of inequality on individual well-being are both normative and comparative. The latter channel is based on the observation that individuals do not live in isolation, and when assessing their own social standing they will compare themselves to individuals in their reference group. When the individual is a member of this group, her well-being is commonly assumed to be negatively affected by those who possess more due to a sentiment of relative deprivation; in a similar vein, the comparison with those who possess less affects her well- 
being positively due to relative satisfaction. When the individual is not currently a member of the reference group, but aspires to be part of the group in question, comparisons with respect to richer individuals in the group may give rise to positive feelings, as the individual anticipates being as well off as the group members once she joins the group. This idea is akin to that of the tunnel effect presented by Hirschman (1973). As is obvious from the above discussion, the measurement of deprivation and satisfaction requires individual-level data.

The normative channel between inequality and well-being works via the individual's disinterested evaluation of economic inequality without her making any comparisons to others: depending on the attitudes and social norms prevailing within a group, the individual can evaluate the income gaps in the group as being either fair or unfair. As such, the summary level of inequality in the individual's country of residence may have an independent effect on her evaluation of living conditions in addition to that reflecting her comparisons of her own situation to better-off and worse-off individuals. For the analysis of the normative channel, aggregate inequality data are sufficient. The following section describes how we measure inequality in the various Barometer datasets.

\section{Measuring inequality}

Our analysis requires information on three different types of inequality measures: (1) an aggregate overall index of differences in the command over economic resources; (2) an individual-level measure that captures the gaps between the individual and all relevant individuals who are betteroff than her; and (3) an analogous individual-level measure of the gaps between the individual and those who are worse-off. The most popular type-1 inequality measure is the Gini coefficient at the country/year level. The two best sources of cross-country and over-time Gini indices available to researchers are the SWIID dataset (Standardized World Income Inequality Database; see Solt 2013) and the WIID dataset (World Income Inequality Database), which is compiled and maintained by UNU-WIDER. There is a third well-known source, the LIS (Luxembourg Income Study Database), but its coverage in terms of both countries and years is lower, which will prevent us using it in the current analysis. Jenkins (2015) and Ferreira et al. (2015), in their evaluation of cross-country inequality datasets, recommend using the WIID. We follow their recommendation and use data from WIID 3.4, released in January 2017, containing Gini indices of income inequality for all the countries and years of our sample.

For the measures of inequality of types 2 and 3 we rely on the information available in the Barometer surveys on the command over economic resources (see also D'Ambrosio and Rodrigues (2008) for a similar application to the study of deprivation in the city of São Paulo). Unfortunately, information on income is not available in many of the Barometer surveys. In order to be able to analyse as many countries and years as possible, we consider different measures of well-being in a non-income framework. These items differ by Barometer, and Table A1 lists the items that we describe below. In each round of the Afrobarometer in our sample, individuals are asked the following questions: 'Over the past year, how often, if ever have you or your family gone without

?' The interviewer asks this question for each of the following four basic necessities: 'Enough food to eat', 'Enough clean water for home use', 'Medicines or medical treatment', and 'Enough fuel to cook your food. The possible answers to this question are: $0=$ never, $1=$ just once or twice, $2=$ several times, $3=$ many times, and $4=$ always. While there is information on a fifth item, ' $A$ cash income', we decided to exclude the latter as the availability of sufficient cash income will very likely determine the answers to all of the other items: someone who does not have enough cash income will also probably not have enough food to eat, clean water for home use, medical treatment, or fuel with which to cook food, leading to an over-count of the sources of deprivation. We use the answers 
to these four questions to first construct an indicator of functioning failure for each individual as the sum of their scores in these four basic domains of a decent life. This indicator thus takes on values between 0 , for individuals who are never deprived in any of the domains, and 16, for individuals who are always deprived in all domains. See Shenga (2010) for an alternative dummy approach using the same dataset, recoding the responses so that 0 refers to never or just once or twice, and 1 refers to several times, many times, or always.

In the Asianbarometer, individual are asked 'Do you or your family own the following?', with possible answers of Yes or No. Among the listed items we here focus on the answers to the questions regarding the following items, which appear in all of the waves: mobile phone, electric fan/cooler, fridge, telephone, TV, cable TV, radio, and camera. The indicator of functioning failure we construct for the Asianbarometer therefore takes on values between 0 , for individuals who have access to all items, and 8 , for individuals who are deprived in every dimension. The questions are similar in the Latinobarometer, and the items we consider here are TV, refrigerator, computer, washing machine, telephone, car, drinking water, and sewerage system. The indicator of functioning failure in the Latinobarometer then also takes on values between 0 , for individuals who have access to all items, and 8, for individuals who are always deprived (although the domains that are evaluated in the Asianbarometer and Latinobarometer are not the same-only three items appear in both lists). The same question is asked in the Eurobarometer and the list of items we include are TV, DVD player, computer, internet access, car, laptop, tablet, and smartphone. This again produces an indicator of functioning failure that takes on values between 0 and 8 .

We formally define the individual indices of relative deprivation and satisfaction by introducing the following notation. Let $\boldsymbol{N}$ denote the set of all positive integers and $\mathbf{R}\left(\mathbf{R}_{+}\right)$the set of all (all non-negative) real numbers. The distinct levels of functioning failures are collected in a vector $\left(q_{1}\right.$, $\ldots, q_{k}$ ), where $k \in N \backslash\{1\}$. Let $\pi_{j}$ indicate the population share of individuals who have the same $q_{j}$ level of functioning failures. The distribution is $(\pi, q) \equiv\left(\pi_{1}, \ldots, \pi_{k} ; q_{1}, \ldots, q_{k}\right), q_{i} \neq q_{j}$ for all $i, j \in\{1, \ldots, k\}$. Let $\Omega$ be the space of all distributions. Define $\bar{q}$ as the illfare-ranked permutation of the vector $q$, so that $\bar{q}_{1} \leq \bar{q}_{2} \ldots \leq \bar{q}_{k}$. In the second step, we calculate well-being indices over these distributions, which we describe below.

The first measure we use in the analysis of individual well-being is the traditional indicator of individual command over economic resources given by the number of functioning failures, $q_{i}$ (see, among many others, Alkire and Foster 2011; Bossert et al. 2013). Here, the higher the value of $q_{\text {is }}$ the more deprived is the individual. As noted above, in the Afrobarometer this variable ranges from 0 , corresponding to the situation of no deprivation (no functioning failures), to 16, the maximum possible value referring to individuals who are always deprived in all dimensions. For the other three Barometer datasets, this variable ranges between 0 (no functioning failures) and 8 (deprivation in all dimensions).

The second group of measures aims to capture the feelings of relative deprivation and satisfaction that an individual experiences from their comparisons to others. Yitzhaki (1979) was the first to introduce the measurement of income deprivation in the economics literature. Rewritten in terms of functioning failures, the index of individual relative deprivation, a function $D_{i}: \Omega \rightarrow \mathrm{R}_{+}$, is given by:

$$
D_{i}(\pi, q)=\sum_{j=1}^{i-1}\left(\bar{q}_{i}-\bar{q}_{j}\right) \pi_{j}
$$


for all $(\pi, q) \in \Omega$. The deprivation from which individual $i$ suffers here is defined as the sum of all functioning-failure differentials with respect to individuals who are less deprived in the society under consideration (i.e. who have fewer functioning failures). Analogously, we can measure the complement to deprivation, satisfaction $S_{i}: \Omega \rightarrow \mathrm{R}_{+}$, as:

$$
S_{i}(\pi, q)=\sum_{j=i+1}^{k}\left(\bar{q}_{j}-\bar{q}_{i}\right) \pi_{j}
$$

for all $(\pi, q) \in \Omega$. This reflects the sum of the functioning-failure differentials with respect to individuals who are more deprived than individual $i$.

The second type of measure we consider with respect to comparisons aims to capture the individual sentiment due to comparisons to others who do not share the exact level of functioning failure, without any further distinction. If we sum the two indices of relative deprivation and satisfaction at the individual level, we obtain the measure of individual alienation, $A_{i}: \Omega \rightarrow \mathbf{R}_{+}$, defined as:

$$
A_{i}(\pi, q)=\sum_{j=1}^{k}\left|\bar{q}_{i}-\bar{q}_{j}\right| \pi_{j}
$$

While deprivation and satisfaction are asymmetric measures, based on comparisons only to those who are better-off or worse-off respectively, alienation is assumed to be experienced with respect to everybody. Davies (2016), interpreting the Gini coefficient, highlights that the individual sum of differences with respect to everyone else, which corresponds to the alienation measure introduced above, $A_{i}$, is the basis for an individual inequality index. The (absolute) Gini coefficient can be interpreted as the average value of this index across the population. Davies also shows that this personal inequality index can be further decomposed into two components corresponding to the relative deprivation and satisfaction measures introduced above, $D_{i}$ and $S_{i}$.

\section{Data, methods, and results}

\subsection{Data}

Our empirical analysis is carried out using data from four different Barometer series, which are repeated cross-section regional surveys on public attitudes towards democracy, governance, economic conditions, and related issues. ${ }^{1}$ Tables A2-A5 list the years we analyse and the size of the sample per country per wave. Our samples of individuals between the ages of 18 and 90 contain information on 43,385 Africans living in 18 countries of the continent in Table A2's Afrobarometer, 13,542 Asians from 9 countries in Table A3's Asianbarometer, 168,278 Latin- and Central-Americans from 18 countries in Table A4's Latinobarometer, and 100,379 Europeans living in 31 different countries in Table A5's Eurobarometer. The datasets are cross-sectional, and not every country appears in every year.

\footnotetext{
${ }^{1}$ See www.afrobarometer.org, www.asianbarometer.org, www.latinobarometro.org, and http:/ / ec.europa.eu/commfrontoffice/publicopinion/index.cfm (the last of these is the Eurobarometer).
} 
Our dependent variables are self-assessed current and future living conditions, which we will denote by $w b_{i t c}$ for individual $i$ in year $t$ in country $c$. In the Afrobarometer, individuals are asked the following question about their current living conditions: 'In general, how would you describe your own present living conditions?', with the possible answers 'Very Bad, 'Fairly Bad', 'Neither Good nor Bad, 'Fairly Good', and 'Very Good'. Regarding the future, the question reads 'Looking abead, do you expect your living conditions in twelve months' time to be better or worse?', with the possible answers 'Much Worse', 'Worse', 'Same', 'Better', and 'Much Better'. In the Asianbarometer the two analogous questions are 'As for your own family, how do you rate your economic situation today?' and 'What do you think the economic situation of your family will be a few years from now?' The possible answers to the first question are 'Very Bad, 'Bad', 'Neither Good nor Bad', 'Good', and 'Very Good' and to the second 'Much Worse', 'A Little Worse', 'About the Same', 'A Little Better', and 'Much Better'. The answers to the two questions in the Latinobarometer are exactly the same, although the wording of the questions is slightly different: 'In general, how would you describe your present economic situation and that of your family?' and 'And in the next 12 months do you think that your economic situation and that of your family will be much better, a little better, about the same, a little worse or much worse compared to the way it is now?'. Two similar questions are asked in the Eurobarometer: 'How would you judge the current financial situation of your housebold?' with possible answers 'Very Bad', 'Rather Bad', 'Rather Good', and 'Very Good'; and 'What are your expectations for the next twelve months: will the next twelve months be better, worse or the same, when it comes to the financial situation of your bousebold?.

To homogenize the analysis as far as possible between different regions, we regroup the first two and last two answers on future living conditions in the Afrobarometer, Latinobarometer, and Asianbarometer to correspond to the categories in the Eurobarometer. The same procedure is not possible for the answers to the current living conditions question, as the median category 'Neither Good nor Bad does not appear in the possible answers in the Eurobarometer. The distributions of the dependent variables averaged over all the years are shown in Figure 1; the distributions for each separate year are very similar and have been omitted. Current living conditions are evaluated as neither good nor bad by the majority of Asians and Central- and Latin-Americans, followed by around 20 per cent of the sample who answer 'Good'. A similar finding holds in Europe, where the majority answer 'Rather Good'. The African distribution is more polarized. The two most common answers are 'Fairly Bad' and 'Fairly Good'. Notably, just under one in five Africans judge their present living conditions as 'Very Bad', a figure that is far higher than that observed in any other region.

Expectations regarding future living conditions reveal a generalized level of optimism everywhere but Europe, where only around 20 per cent expect the future financial situation of the household to be better than it is today. The analogous optimism figures are at least 60 per cent in Asia and Africa, and 45 per cent in Central and Latin America. Only around 20 per cent of Africans, Centraland Latin-Americans, and Europeans expect the future to be worse than today, while among the more optimistic Asians this figure is closer to 10 per cent. (For a discussion on optimism and poverty in Africa, see Graham and Hoover 2007.) 
Figure 1: The distribution of the dependent variables

\section{A: Afrobarometer}
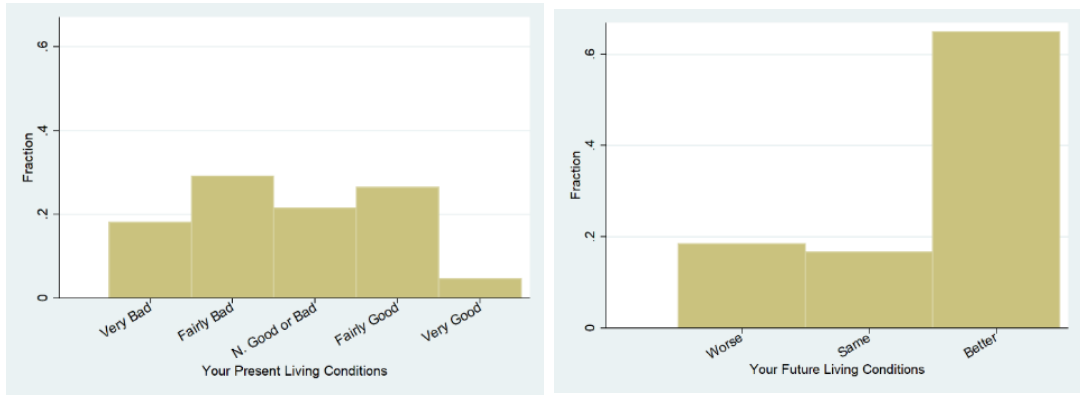

\section{B: Asianbarometer}
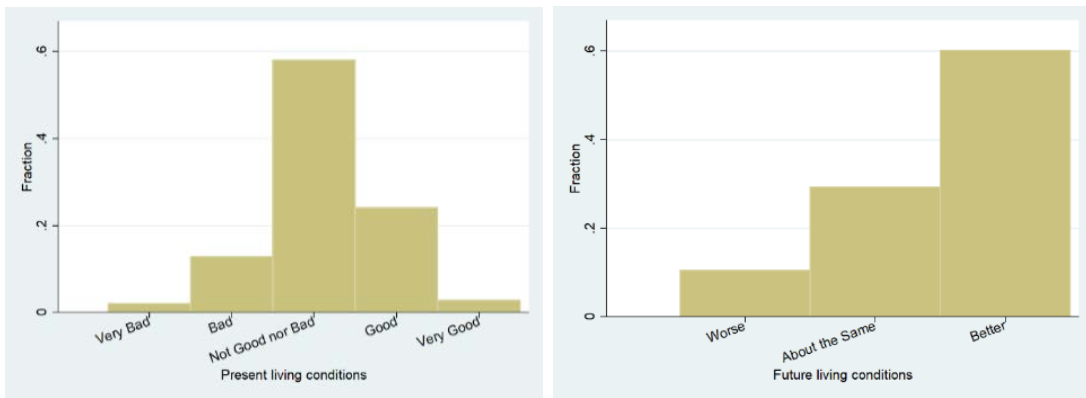

\section{C: Latinobarometer}

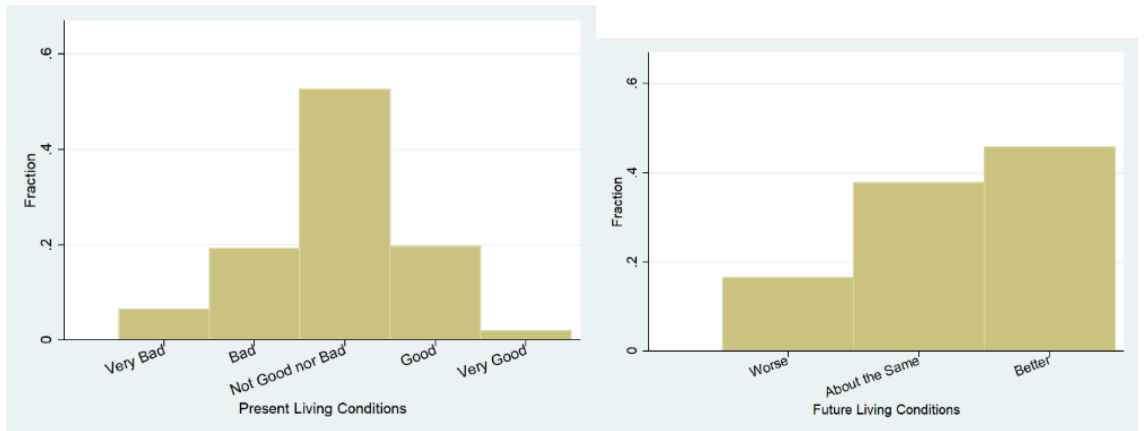

\section{D: Eurobarometer}
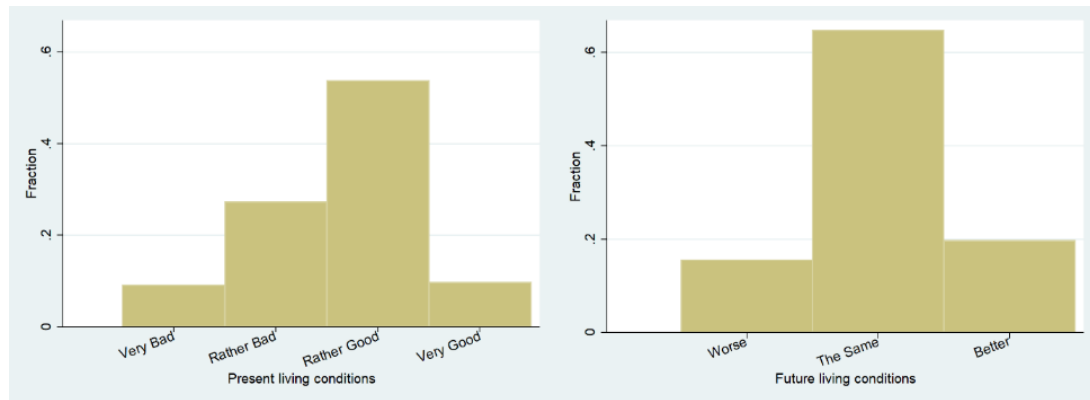

Source: Authors', based on data from the Afrobarometer, Asianbarometer, Latinobarometer, and Eurobarometer.

\subsection{Method}

When we carry out our multivariate regression analyses of current and future living conditions, we will control for a number of individual-level variables so that we compare like with like. In particular, we will control for age, age-squared, gender, the highest level of education achieved (with three levels: at most primary, at most secondary, and at least post-secondary) and labour-force status 
(unemployed, employed, and out of the labour-force). In Asian and African countries we will include an additional control for living in urban or rural areas. All regressions will include wave and country dummies, although their associated coefficients will not be reported for space reasons.

The descriptive statistics for the variables that appear in our sample are shown in Tables 1-4 for our four different Barometer surveys. The majority of the sample are of working age and employed (except in the Afrobarometer). In the Afrobarometer and Asianbarometer surveys that provide information on the area of residence, the majority live in rural areas. Regarding education, the most common category in Africa and Central and Latin America is having at most achieved a primary level of education, while in Asia and Europe the most common category is at least secondary level.

Table 1: Descriptive statistics: Afrobarometer

\begin{tabular}{lcccc}
\hline & Mean & SD & Min. & Max. \\
\hline Present living conditions [1-5] & 2.67 & 1.16 & 1 & 5 \\
Future living conditions [1-3] & 2.46 & 0.79 & 1 & 3 \\
No. functioning failures [0-16] & 4.25 & 3.76 & 0 & 16 \\
Deprivation & 1.86 & 2.17 & 0 & 13.90 \\
Satisfaction & 1.86 & 1.52 & 0 & 9.29 \\
Alienation & 3.72 & 1.51 & 0 & 13.92 \\
Gini & 46.31 & 9.60 & 24 & 64.79 \\
Age & 36.98 & 14.43 & 19 & 89 \\
Female & 0.50 & 0.50 & 0 & 1 \\
At most primary education & 0.56 & 0.50 & 0 & 1 \\
At most secondary education & 0.34 & 0.47 & 0 & 1 \\
At least post-secondary education & 0.11 & 0.31 & 0 & 1 \\
Employed & 0.34 & 0.47 & 0 & 1 \\
Unemployed & 0.30 & 0.46 & 0 & 1 \\
Out of the labour-force & 0.36 & 0.48 & 0 & 1 \\
Urban & 0.37 & 0.48 & 0 & 1
\end{tabular}

Source: Authors', based on the Afrobarometer.

Table 2: Descriptive statistics: Asianbarometer

\begin{tabular}{lcccc}
\hline & Mean & SD & Min. & Max. \\
\hline Present living conditions [1-5] & 3.18 & 0.73 & 1 & 5 \\
Future living conditions [1-3] & 2.49 & 0.68 & 1 & 3 \\
No. functioning failures [0-8] & 3.87 & 2.12 & 0 & 8 \\
Deprivation & 0.90 & 0.84 & 0 & 6.05 \\
Satisfaction & 0.90 & 0.95 & 0 & 5.96 \\
Alienation & 1.81 & 0.70 & 1.02 & 6.05 \\
Gini & 39.88 & 3.79 & 33.44 & 46.05 \\
Age & 41.85 & 14.34 & 20 & 89 \\
Female & 0.50 & 0.50 & 0 & 1 \\
At most primary education & 0.40 & 0.49 & 0 & 1 \\
At most secondary education & 0.45 & 0.50 & 0 & 1 \\
At least post-secondary education & 0.15 & 0.36 & 0 & 1 \\
Employed & 0.69 & 0.46 & 0 & 1 \\
Unemployed & 0.08 & 0.28 & 0 & 1 \\
Out of the labour-force & 0.22 & 0.42 & 0 & 1 \\
Urban & 0.39 & 0.49 & 0 & 1 \\
\hline
\end{tabular}

Source: Authors', based on the Asianbarometer. 
Table 3: Descriptive statistics: Latinobarometer

\begin{tabular}{lcccc}
\hline & Mean & SD & Min. & Max. \\
\hline Present living conditions [1-5] & 2.91 & 0.85 & 1 & 5 \\
Future living conditions [1-3] & 2.29 & 0.73 & 1 & 3 \\
No. functioning failures [0-8] & 3.31 & 2.04 & 0 & 8 \\
Deprivation & 0.92 & 0.94 & 0 & 6.90 \\
Satisfaction & 0.92 & 0.90 & 0 & 6.51 \\
Alienation & 1.83 & 0.73 & 0.30 & 6.90 \\
Gini & 51.08 & 4.52 & 36 & 59.10 \\
Age & 41.00 & 15.67 & 20 & 90 \\
Female & 0.51 & 0.50 & 0 & 1 \\
At most primary education & 0.46 & 0.50 & 0 & 1 \\
At most secondary education & 0.36 & 0.48 & 0 & 1 \\
At least post-secondary education & 0.18 & 0.38 & 0 & 1 \\
Employed & 0.59 & 0.49 & 0 & 1 \\
Unemployed & 0.07 & 0.25 & 0 & 1 \\
Out the labour-force & 0.35 & 0.48 & 0 & 1 \\
\hline
\end{tabular}

Source: Authors', based on the Latinobarometer.

Table 4: Descriptive statistics: Eurobarometer

\begin{tabular}{lcccc}
\hline & Mean & SD & Min. & Max. \\
\hline Present living conditions [1-4] & 2.64 & 0.78 & 1 & 4 \\
Future living conditions [1-3] & 2.04 & 0.59 & 1 & 3 \\
No. functioning failures [0-8] & 3.21 & 2.19 & 0 & 7 \\
Deprivation & 1.16 & 1.17 & 0 & 5.62 \\
Satisfaction & 1.16 & 0.98 & 0 & 5.05 \\
Alienation & 2.31 & 0.70 & 1.17 & 5.62 \\
Gini & 30.56 & 4.15 & 23.70 & 38.60 \\
Age & 52.37 & 16.70 & 18 & 90 \\
Female & 0.55 & 0.50 & 0 & 1 \\
At most primary education & 0.32 & 0.47 & 0 & 1 \\
At most secondary education & 0.42 & 0.49 & 0 & 1 \\
At least post-secondary education & 0.26 & 0.44 & 0 & 1 \\
Employed & 0.51 & 0.50 & 0 & 1 \\
Unemployed & 0.10 & 0.30 & 0 & 1 \\
Out of the labour-force & 0.39 & 0.49 & 0 & 1
\end{tabular}

Source: Authors', based on the Eurobarometer

The general model of subjective well-being we estimate is of the following form:

$$
w b_{i t c}=\beta_{1}+\beta_{2} M_{i t c}+\beta_{3} \text { Gini }_{t c}+\beta_{4} X_{i t c}+\alpha_{c}+\lambda_{t}+\grave{o ̀}_{i t c}
$$

Where $q_{i t}$ is the count of functioning failures (which here is a measure of the absolute living standards of the individual); $M_{i t c}$ refers to one of the relative inequality measures discussed in Section 2 to assess the comparative perspective of inequality; and Gini $t_{t c}$ is the Gini index, capturing individuals' normative reactions to inequality.

The specification in equation 4 allows us to estimate the absolute, comparative, and normative components of subjective well-being with respect to economic resources. For the indices in which a comparison group has to be specified, we impose that this group consist of individuals living in the same country at a given point in time. The vector $X_{i t}$ includes individual-level control variables 
(age, gender, urban residence, education, and labour-force status), while $a_{c}$ and $\lambda_{t}$ are respectively the country and wave fixed effects. We present results here based on linear (OLS) estimation: the pattern of results is the same using non-linear estimation techniques such as ordered probit or ordered logit. We standardize both the dependent variable and all of the objective measures of deprivation, so that the estimated coefficients are $\beta$ s, representing the effect in terms of the standard deviation of the dependent variable of a one standard-deviation change in the objective measure on the right-hand side. All regressions have standard errors clustered at the country/year level.

\subsection{Results}

The control variables attract the following estimated coefficients (see Tables A6-A9). As in the subjective well-being literature, the relationship between age and current living conditions is Ushaped, with the lowest level at around age 50. Women and those living in urban areas have a more negative evaluation of their living conditions. With respect to labour-force status, we find a negative estimated coefficient for the unemployed and a positive coefficient for the employed, as compared to our reference category of individuals who are out of the labour-force. Education is very strongly correlated with current living conditions, which is to be expected if it is acting as a proxy for income. A similar results hold for the evaluation of the future living conditions, even though the size of the coefficients is smaller.

Tables 5 through 8 show the estimated coefficients of our key explanatory variables (which also appear at the head of the full set of results in Tables A6-A9). There are two specifications, depending on how the comparative component is specified, as two separate sums of the differences with worse-off and better-off individuals (deprivation and satisfaction in columns 1 and 3), or as a global sum of differences with respect to everybody (alienation in columns 2 and 4). The first coefficient in each regression refers to the absolute component of standards of living, the number of functioning failures, qit; the following three entries then capture the comparative effect of inequality via relative deprivation and satisfaction together, or alienation where the gaps between the individual and the better-off and worse-off individuals are treated symmetrically; the final estimated coefficient is that on the Gini coefficient that measures the normative effect of inequality.

Table 5: Economic conditions and inequality: OLS results in the Afrobarometer

\begin{tabular}{|c|c|c|c|c|}
\hline & \multicolumn{2}{|c|}{ Present } & \multicolumn{2}{|c|}{ Future } \\
\hline & (1) & $(2)$ & (3) & $(4)$ \\
\hline \multirow[t]{2}{*}{ No. functioning failures } & $-0.203^{\star \star \star}$ & $-0.231^{\star \star \star}$ & $-0.169^{\star \star \star}$ & $-0.144^{\star \star \star}$ \\
\hline & $(0.050)$ & $(0.012)$ & $(0.044)$ & $(0.012)$ \\
\hline \multirow[t]{2}{*}{ Deprivation } & 0.017 & & $0.053^{\star}$ & \\
\hline & $(0.034)$ & & $(0.031)$ & \\
\hline \multirow[t]{2}{*}{ Satisfaction } & $0.037^{\star}$ & & 0.017 & \\
\hline & $(0.021)$ & & $(0.019)$ & \\
\hline \multirow[t]{2}{*}{ Alienation } & & $0.028^{\star \star}$ & & $0.027^{\star \star}$ \\
\hline & & $(0.012)$ & & $(0.012)$ \\
\hline \multirow[t]{2}{*}{ Gini } & 0.100 & 0.097 & $0.128^{*}$ & $0.130^{*}$ \\
\hline & $(0.076)$ & $(0.076)$ & $(0.074)$ & $(0.074)$ \\
\hline No.observations & 43,865 & 43,865 & 38,514 & 38,514 \\
\hline Adjusted $\mathrm{R}^{2}$ & 0.140 & 0.140 & 0.135 & 0.135 \\
\hline
\end{tabular}

Notes: clustered standard errors are in parentheses. The controls include the variables in Table 1, and wave and country fixed effects. ${ }^{*} p<0.1,{ }^{* *} p<0.05,{ }^{* \star *} p<0.01$.

Source: Authors' calculations, based on data from the Afrobarometer. 
Table 6: Economic conditions and inequality: OLS results in the Asianbarometer

\begin{tabular}{|c|c|c|c|c|}
\hline & \multicolumn{2}{|c|}{ Present } & \multicolumn{2}{|c|}{ Future } \\
\hline & $(1)$ & (2) & (3) & $(4)$ \\
\hline \multirow[t]{2}{*}{ No. functioning failures } & -0.002 & $-0.173^{\star \star \star}$ & 0.075 & $-0.053^{\star \star \star}$ \\
\hline & $(0.068)$ & $(0.027)$ & $(0.054)$ & $(0.011)$ \\
\hline \multirow[t]{2}{*}{ Deprivation } & $-0.098^{\star \star}$ & & $-0.064^{\star \star}$ & \\
\hline & $(0.039)$ & & $(0.032)$ & \\
\hline \multirow[t]{2}{*}{ Satisfaction } & 0.034 & & 0.036 & \\
\hline & $(0.029)$ & & $(0.022)$ & \\
\hline \multirow[t]{2}{*}{ Alienation } & & -0.027 & & -0.012 \\
\hline & & $(0.017)$ & & $(0.015)$ \\
\hline \multirow[t]{2}{*}{ Gini } & $-0.064^{\star \star \star}$ & $-0.067^{\star \star}$ & $-0.038^{\star \star}$ & $-0.040^{\star}$ \\
\hline & $(0.013)$ & $(0.026)$ & $(0.015)$ & $(0.021)$ \\
\hline No. observations & 13,542 & 13,542 & 13,542 & 13,542 \\
\hline Adjusted $\mathrm{R}^{2}$ & 0.110 & 0.110 & 0.240 & 0.240 \\
\hline
\end{tabular}

Notes: clustered standard errors are in parentheses. The controls include the variables in Table 2, and wave and country fixed effects. ${ }^{*} p<0.1,{ }^{* \star} p<0.05,{ }^{* \star \star} p<0.01$.

Source: Authors' calculations, based on data from the Asianbarometer.

Table 7: Economic conditions and inequality: OLS results in the Latinobarometer

\begin{tabular}{|c|c|c|c|c|}
\hline & \multicolumn{2}{|c|}{ Present } & \multicolumn{2}{|c|}{ Future } \\
\hline & $(1)$ & $(2)$ & $(3)$ & $(4)$ \\
\hline \multirow[t]{2}{*}{ No. functioning failures } & $-0.144^{\star \star \star *}$ & $-0.165^{\star \star \star}$ & $-0.082^{\star \star \star}$ & $-0.068^{\star \star \star}$ \\
\hline & $(0.022)$ & $(0.009)$ & $(0.021)$ & $(0.007)$ \\
\hline \multirow[t]{2}{*}{ Deprivation } & 0.002 & & $0.022^{\star \star}$ & \\
\hline & $(0.011)$ & & $(0.009)$ & \\
\hline \multirow[t]{2}{*}{ Satisfaction } & $0.024^{\star *}$ & & 0.006 & \\
\hline & $(0.012)$ & & $(0.011)$ & \\
\hline \multirow[t]{2}{*}{ Alienation } & & $0.010^{\star \star}$ & & $0.011^{\star \star \star}$ \\
\hline & & $(0.005)$ & & $(0.004)$ \\
\hline \multirow[t]{2}{*}{ Gini } & -0.035 & -0.035 & $0.138^{\star \star \star}$ & $0.137^{\star \star \star}$ \\
\hline & $(0.048)$ & $(0.048)$ & $(0.046)$ & $(0.046)$ \\
\hline No. observations & 168,279 & 168,279 & 135,216 & 135,216 \\
\hline Adjusted $\mathrm{R}^{2}$ & 0.135 & 0.135 & 0.077 & 0.077 \\
\hline
\end{tabular}

Notes: clustered standard errors are in parentheses. The controls include the variables in Table 3 , and wave and country fixed effects. ${ }^{*} p<0.1,{ }^{* *} p<0.05,{ }^{* \star *} p<0.01$.

Source: Authors' calculations, based on data from the Latinobarometer. 
Table 8: Economic conditions and inequality: OLS results in the Eurobarometer

\begin{tabular}{|c|c|c|c|c|}
\hline & \multicolumn{2}{|c|}{ Present } & \multicolumn{2}{|c|}{ Future } \\
\hline & (1) & $(2)$ & (3) & (4) \\
\hline \multirow[t]{2}{*}{ No. functioning failures } & 0.019 & $-0.202^{\star \star \star}$ & 0.143 & $-0.074^{\star \star \star}$ \\
\hline & $(0.095)$ & $(0.006)$ & $(0.136)$ & $(0.008)$ \\
\hline \multirow[t]{2}{*}{ Deprivation } & $-0.099^{*}$ & & -0.100 & \\
\hline & $(0.052)$ & & $(0.072)$ & \\
\hline \multirow[t]{2}{*}{ Satisfaction } & $0.115^{\star \star \star}$ & & $0.110^{\star}$ & \\
\hline & $(0.041)$ & & $(0.062)$ & \\
\hline \multirow[t]{2}{*}{ Alienation } & & $0.011^{\star \star}$ & & $0.009^{* *}$ \\
\hline & & $(0.005)$ & & (0.004) \\
\hline \multirow[t]{2}{*}{ Gini } & 0.035 & 0.020 & 0.061 & 0.048 \\
\hline & $(0.035)$ & $(0.034)$ & $(0.040)$ & $(0.036)$ \\
\hline Observations & 100,379 & 100,379 & 97,778 & 97,778 \\
\hline Adjusted $\mathrm{R}^{2}$ & 0.305 & 0.305 & 0.082 & 0.082 \\
\hline
\end{tabular}

Notes: clustered standard errors are in parentheses. The controls include the variables in Table 4, and wave and country fixed effects. ${ }^{*} p<0.1,{ }^{* \star} p<0.05,{ }^{* \star \star} p<0.01$.

Source: Authors' calculations, based on data from the Eurobarometer.

Functioning failures reduce the evaluation of current living standards, as might be expected: the more objectively deprived the individual is, the lower the evaluation of their current life. The effect size is large here: a one standard-deviation rise in the index in question reduces the evaluation of current living conditions by around one-quarter of a standard deviation. The results for the expectations of future living conditions are similar, although the effect size is, on average, lower, and in one instance, for the Eurobarometer in the first specification, positive.

When relative comparisons are introduced in the form of deprivation and satisfaction in the evaluation of the present, they are both separately significant only in the Eurobarometer. Here, seeing oneself better-off than others increases the evaluation of the current living conditions while comparisons with the better-off have the opposite effect. In the other continents, only one of the two is significant. In Asia it is the negative effect of relative deprivation that matters, while in Africa and Central and Latin America what counts is the positive effect of satisfaction with respect to those who are worse-off. The results for expected future living conditions for Europeans and Asians are not qualitatively different from those with respect to their current living conditions, while in the Afrobarometer and Latinobarometer being more deprived now attracts a positive and significant coefficient (with the coefficient on deprivation being twice as large as that on satisfaction).

While the (positive, but not always significant) satisfaction result is to be expected, the positive effect of comparisons to the better-off, as measured by $D_{i}$, is more commonly found in volatile socioeconomic environments, such as in the earlier stages of economic development, which can be argued to apply to many of the African and Central- and Latin-American countries in our sample. This positive effect of others' good fortune on the individual's own evaluation of their life is known in the literature as the 'tunnel effect' of Hirschman (1973): the presence of better-off individuals here does not produce a sentiment of relative deprivation due to social comparisons, but rather a positive signal that the individual may improve their own situation in the future (see Senik (2004) for a similar result in Russia during the 1990s, and Grosfeld and Senik (2010) for the analysis of attitudes to inequality in a growing country, Poland; see also D'Ambrosio and Frick (2012) for a dynamic version of the tunnel effect). 
When relative comparisons are introduced in the form of differences to others without further distinction between the better-off and worse-off, the positive effect prevails everywhere except in Asia, which was to be expected from the previous results where only relative deprivation mattered (the satisfaction coefficient in columns 1 and 3 is insignificant). Europe is of particular interest here, where both deprivation and satisfaction had independent and significant effects: when added together, what prevails is the positive effect of satisfaction.

The normative effect of inequality is measured by the coefficient on the Gini index. This is not calculated from within the Barometer data, but is matched in as an aggregate measure of income inequality from an independent source, the WIID. The coefficient on the Gini index captures the effect of the individual's disinterested evaluation of economic inequality without making any comparisons to others. The results are very mixed across our regions of the world (arguably mirroring the wide variety of findings in the existing literature summarized by Clark and D’Ambrosio (2015)).

Aggregate inequality in the country of residence attracts a positive, but insignificant, estimated coefficient in the Afrobarometer and the Eurobarometer, and a negative, but insignificant, estimated coefficient in the Latinobarometer. The only significant estimated coefficient on inequality for current living conditions is negative in the Asianbarometer. The results regarding the correlation between the Gini and future living conditions are more significant in general, but still not uniform: this correlation is positive for Africans and Central- and Latin-Americans, negative for Asians, and insignificant for Europeans.

\section{Conclusion}

We have appealed to repeated cross-section information on well-being, as captured by current and future evaluations of standards of living, from across the world in four different Barometer series. We relate these well-being measures to not only one's own economic resources but also the distribution of resources at the country-year level. With respect to the latter, we divide this distribution up into a comparative component (as measured by the gaps between those who are richer than the individual- deprivation - and the sum of gaps between those who are poorersatisfaction) and the normative evaluation of distribution (conditional on these gaps), given by the Gini coefficient.

We find that all of the absolute, comparative, and normative components of inequality matter for individuals' evaluations of their current and future living conditions, which underlines the multifaceted nature of the evaluation of standard of living. While the positive correlation between one's own resources and life evaluations is unsurprising, the relationship of the latter to the distribution of resources is anything bar standard across the four regions of the world that we have considered. The 'typical' pattern of a negative effect of gaps to the better-off but a positive effect of gaps to the worse-off turns out to hold only in Europe. In some other parts of the world, gaps to the better-off either have no correlation with life evaluations or, in Africa and Central and Latin America, are associated with more positive expectations of one's future life. The positive estimated coefficient on gaps to the worse-off is found more often, but is notably absent in Asia, a result that surely bear furthers research. Last, the Gini coefficient itself exhibits a wide variety of estimated coefficients, being negatively correlated with current life evaluation in Asia only, and attracting insignificant coefficients everywhere else. The story is somewhat more uniform regarding future life evaluations, where the Gini coefficient attracts a positive and significant estimated coefficient in Africa and Central and Latin America (in line with the positive effect of gaps to the better-off noted above), but a negative significant coefficient in Asia. Clearly the nature 
of the relationship between the distribution of the resources and measures of individual well-being over time is not universal, and merits substantial separate research in different regions of the world.

\section{References}

Akay, A., and P. Martinsson (2011). 'Does Relative Income Matter for the Very Poor? Evidence from Rural Ethiopia'. Economics Letters, 110: 213-15.

Alkire, S. and J.E. Foster (2011). 'Counting and Multidimensional Poverty Measurement'. Journal of Public Economics, 95: 476-87.

Bookwalter, J., and D. Dalenberg (2010). 'Relative to What or Whom? The Importance of Norms and Relative Standing to Well-Being in South Africa'. World Development, 38: 345-55.

Bossert, W., C. D'Ambrosio, and S.R. Chakravarty (2013). 'Multidimensional Poverty and Material Deprivation with Discrete Data'. Review of Income and Wealth, 59: 29-43.

Clark, A.E., and C. D’Ambrosio (2015). 'Attitudes to Income Inequality: Experimental and Survey Evidence'. In A. Atkinson and F. Bourguignon (eds.), Handbook of Income Distribution Volume $2 A$. Amsterdam: Elsevier.

Clark, A.E. and C. D'Ambrosio (2017). 'Living Conditions and Well-being: Evidence from African Countries’. WIDER Working Paper 2017/209. Helsinki: UNU-WIDER.

Clark, A.E., and C. Senik (eds) (2014). Happiness and Economic Growth: Lessons from Developing Countries. Oxford: Oxford University Press.

D'Ambrosio, C., and J. Frick (2012). 'Individual Well-Being in a Dynamic Perspective'. Economica, 79: 284-302.

D'Ambrosio, C. and R.I. Rodrigues (2008). 'Deprivation in the São Paulo Districts: Evidence from 2000'. World Development, 36: 1094-112.

Davies, J.B. (2016). 'The Gini Coefficient and Personal Inequality Measurement'. Mimeo. London, Canada: University of Western Ontario.

Ferreira, F.H., N. Lustig, and D. Teles (2015). 'Appraising Cross-National Income Inequality Databases: An Introduction'. Journal of Economic Inequality, 13: 497-526.

Graham, C., and M. Hoover (2007). 'Optimism and Poverty in Africa: Adaptation or a Means to Survival?’ Afrobarometer Working Paper 76. Accra: Afrobarometer.

Grosfeld, I., and C. Senik (2010). 'The Emerging Aversion to Inequality: Evidence from Poland 1992-2005'. Economics of Transition, 18: 1-26.

Hirshman, A.O. (1973). 'The Changing Tolerance for Income Inequality in the Course of Economic Development'. Quarterly Journal of Economics, 87: 544-66.

Jenkins, S.P. (2015). 'World Income Inequality Databases: An Assessment of WIID and SWIID'. Journal of Economic Inequality, 13: 629-71.

Lentz, E. (2017). 'Keeping Up with the Neighbors? Reference Groups in Ghana'. Economic Development and Cultural Change, 66: 91-112.

Senik, C. (2004). 'When Information Dominates Comparison: Learning from Russian Subjective Panel Data'. Journal of Public Economics, 88: 2099-123.

Shenga, C. (2010). 'Economic Conditions, Living Conditions and Poverty in Mozambique'. Afrobarometer Briefing Paper 87. Accra: Afrobarometer 
Solt, F. (2013) 'SWIID: The Standardized World Income Inequality Database, Version 4.0'. Statistical database. Iowa City: University of Iowa.

Van de Werfhorst, H.G., and W. Salverda (2012). 'Consequences of Economic Inequality: Introduction to a Special Issue'. Research in Social Stratification and Mobility, 30: 377-87.

Yitzhaki, S. (1979). 'Relative Deprivation and the Gini Coefficient'. Quarterly Journal of Economics, 93: 321-24. 


\section{Appendix}

Table A1: List of items per dataset

\begin{tabular}{llll}
\hline Afrobarometer & Asianbarometer & Latinobarometer & Eurobarometer \\
\hline Food & Mobile phone & TV & TV \\
Water & Cooler & Refrigerator & DVD player \\
Medical care & Fridge & Computer & Computer \\
Cooking fuel & Telephone & Washing machine & Internet access \\
& TV & Telephone & Car \\
& Radio & Car & Laptop \\
& Camera & Drinking water & Tablet \\
& Cable TV & Sewerage system & Smartphone
\end{tabular}

Source: Authors', based on the Afrobarometer, Asianbarometer, Latinobarometer, and Eurobarometer.

Table A2: Number of observations per country per wave: Afrobarometer

\begin{tabular}{|c|c|c|c|c|c|}
\hline & 2003 & 2004 & 2008 & 2010 & Total \\
\hline Botswana & 1,112 & 0 & 0 & 1,126 & 2,238 \\
\hline Burkina Faso & 0 & 0 & 1,080 & 0 & 1,080 \\
\hline Cape Verde & 1,140 & 0 & 1,189 & 0 & 2,329 \\
\hline Egypt & 0 & 0 & 0 & 1,148 & 1,148 \\
\hline Ghana & 0 & 1,128 & 0 & 0 & 1,128 \\
\hline Kenya & 0 & 1,209 & 0 & 0 & 1,209 \\
\hline Lesotho & 1,156 & 0 & 0 & 0 & 1,156 \\
\hline Liberia & 0 & 0 & 1,143 & 0 & 1,143 \\
\hline Madagascar & 0 & 0 & 0 & 1,138 & 1,138 \\
\hline Malawi & 0 & 1,073 & 1,086 & 2,252 & 4,411 \\
\hline Mali & 1,189 & 0 & 1,171 & 0 & 2,360 \\
\hline Mozambique & 1,044 & 0 & 1,016 & 0 & 2,060 \\
\hline Namibia & 1,126 & 0 & 1,141 & 1,112 & 3,379 \\
\hline Nigeria & 2,253 & 0 & 2,157 & 2,215 & 6,625 \\
\hline Senegal & 1,045 & 1,101 & 0 & 0 & 2,146 \\
\hline South Africa & 0 & 2,256 & 2,258 & 0 & 4,514 \\
\hline Tanzania & 1,162 & 0 & 0 & 0 & 1,162 \\
\hline Uganda & 0 & 2,294 & 2,345 & 0 & 4,639 \\
\hline Total & 11,227 & 9,061 & 14,586 & 8,991 & 43,685 \\
\hline
\end{tabular}

Source: Authors', based on the Afrobarometer. 
Table A3: Number of observations per country per wave: Asianbarometer

\begin{tabular}{lccc}
\hline & 2006 & 2010 & Total \\
\hline Cambodia & 716 & 1,098 & 1,814 \\
Indonesia & 0 & 1,286 & 1,286 \\
\hline Japan & 767 & 1,465 & 2,232 \\
Malaysia & 972 & 1,034 & 2,006 \\
Mongolia & 1,086 & 0 & 1,086 \\
Philippines & 0 & 1,042 & 1,042 \\
Singapore & 0 & 666 & 666 \\
Thailand & 970 & 946 & 1,916 \\
Total & 4,819 & 5,825 & 13,542 \\
Vietnam & 1,075 & 419 & 1,494 \\
\hline
\end{tabular}

Source: Authors', based on the Asianbarometer. 
Table A4: Number of observations per country per wave: Latinobarometer

\begin{tabular}{|c|c|c|c|c|c|c|c|c|c|c|c|c|c|}
\hline & 1998 & 2000 & 2001 & 2002 & 2003 & 2004 & 2005 & 2006 & 2007 & 2008 & 2009 & 2010 & Total \\
\hline Argentina & 1,054 & 1,067 & 1,008 & 1,053 & 1,095 & 1,080 & 1,057 & 0 & 1,076 & 1,097 & 1,084 & 1,110 & 11,781 \\
\hline Bolivia & 539 & 879 & 934 & 1,088 & 0 & 1,068 & 1,018 & 1,050 & 1,052 & 1,056 & 1,077 & 0 & 9,761 \\
\hline Chile & 1,072 & 1,066 & 0 & 0 & 1,106 & 0 & 0 & 1,103 & 0 & 0 & 1,113 & 0 & 5,460 \\
\hline Colombia & 0 & 1,118 & 1,105 & 1,087 & 1,099 & 1,101 & 1,089 & 0 & 1,094 & 1,112 & 1,066 & 1,108 & 10,970 \\
\hline Dominican Rep. & 0 & 0 & 0 & 0 & 0 & 925 & 912 & 805 & 794 & 856 & 799 & 905 & 5,996 \\
\hline Ecuador & 0 & 1,081 & 1,051 & 1,087 & 1,111 & 1,106 & 1,078 & 1,114 & 1,100 & 1,108 & 1,108 & 1,103 & 12,044 \\
\hline El Salvador & 782 & 900 & 899 & 913 & 940 & 929 & 926 & 905 & 828 & 826 & 826 & 877 & 10,565 \\
\hline Guatemala & 0 & 788 & 0 & 876 & 903 & 911 & 0 & 808 & 0 & 0 & 0 & 893 & 5,179 \\
\hline Honduras & 726 & 0 & 905 & 904 & 912 & 906 & 918 & 820 & 747 & 858 & 858 & 891 & 9,475 \\
\hline Mexico & 1,044 & 0 & 0 & 1,132 & 0 & 1,047 & 1,061 & 1,103 & 0 & 1,118 & 0 & 1,128 & 7,633 \\
\hline Panama & 0 & 907 & 879 & 928 & 910 & 933 & 930 & 914 & 872 & 903 & 903 & 900 & 9,979 \\
\hline Paraguay & 0 & 0 & 515 & 514 & 531 & 540 & 1,079 & 1,034 & 1,025 & 1,066 & 1,082 & 1,065 & 8,451 \\
\hline Peru & 885 & 895 & 917 & 1,099 & 1,100 & 1,100 & 1,082 & 1,094 & 1,073 & 1,064 & 1,091 & 1,086 & 12,486 \\
\hline Uruguay & 1,090 & 1,116 & 1,124 & 1,109 & 1,088 & 1,102 & 1,119 & 1,119 & 1,074 & 1,121 & 1,091 & 1,071 & 13,224 \\
\hline Venezuela & 0 & 1,088 & 1,098 & 1,091 & 1,100 & 1,100 & 1,101 & 1,111 & 1,093 & 1,093 & 0 & 1,082 & 10,957 \\
\hline Total & 9,118 & 12,589 & 13,030 & 14,657 & 12,940 & 15,818 & 16,176 & 14,871 & 13,724 & 15,206 & 14,989 & 15,161 & 168,279 \\
\hline
\end{tabular}

Source: Authors', based on the Latinobarometer. 
Table A5: Number of observations per country per wave: Eurobarometer

\begin{tabular}{|c|c|c|c|c|c|}
\hline & $\begin{array}{l}2014 \\
\text { (April) }\end{array}$ & $\begin{array}{c}2014 \\
\text { (November) }\end{array}$ & $\begin{array}{l}2015 \\
\text { (April) }\end{array}$ & $\begin{array}{c}2015 \\
\text { (November) }\end{array}$ & Total \\
\hline Austria & 852 & 941 & 927 & 921 & 3,641 \\
\hline Belgium & 921 & 949 & 913 & 929 & 3,718 \\
\hline Bulgaria & 930 & 921 & 951 & 922 & 3,724 \\
\hline Croatia & 888 & 889 & 890 & 894 & 3,561 \\
\hline Cyprus & 455 & 443 & 447 & 459 & 1,804 \\
\hline Czech Republic & 978 & 976 & 920 & 928 & 3,802 \\
\hline Denmark & 927 & 900 & 932 & 905 & 3,664 \\
\hline Estonia & 926 & 895 & 890 & 893 & 3,604 \\
\hline Finland & 913 & 901 & 913 & 897 & 3,624 \\
\hline France & 913 & 929 & 893 & 940 & 3,675 \\
\hline Germany & 1,340 & 1,449 & 1,376 & 1,422 & 5,587 \\
\hline Greece & 921 & 922 & 927 & 922 & 3,692 \\
\hline Hungary & 930 & 1,009 & 979 & 986 & 3,904 \\
\hline Ireland & 1,203 & 1,193 & 0 & 0 & 2,396 \\
\hline Italy & 871 & 880 & 872 & 870 & 3,493 \\
\hline Latvia & 890 & 897 & 894 & 909 & 3,590 \\
\hline Lithuania & 892 & 892 & 895 & 906 & 3,585 \\
\hline Luxembourg & 446 & 459 & 456 & 465 & 1,826 \\
\hline Macedonia & 0 & 942 & 0 & 0 & 942 \\
\hline Malta & 470 & 471 & 467 & 455 & 1,863 \\
\hline Montenegro & 0 & 416 & 0 & 0 & 416 \\
\hline Netherlands & 943 & 940 & 921 & 952 & 3,756 \\
\hline Poland & 898 & 876 & 858 & 787 & 3,419 \\
\hline Portugal & 857 & 901 & 908 & 866 & 3,532 \\
\hline Romania & 906 & 882 & 877 & 865 & 3,530 \\
\hline Serbia & 0 & 838 & 839 & 771 & 2,448 \\
\hline Slovakia & 893 & 939 & 928 & 936 & 3,696 \\
\hline Slovenia & 940 & 956 & 897 & 900 & 3,693 \\
\hline Spain & 922 & 939 & 884 & 892 & 3,637 \\
\hline Sweden & 994 & 950 & 969 & 957 & 3,870 \\
\hline United Kingdom & 871 & 917 & 889 & 919 & 3,596 \\
\hline Total & 24,902 & 27,414 & 24,516 & 24,470 & 100,379 \\
\hline
\end{tabular}

Source: Authors', based on the Eurobarometer. 
Table A6: Economic conditions and inequality: OLS results in the Afrobarometer-all controls

\begin{tabular}{|c|c|c|c|c|}
\hline & \multicolumn{2}{|c|}{ Present } & \multicolumn{2}{|c|}{ Future } \\
\hline & $(1)$ & (2) & (3) & (4) \\
\hline \multirow[t]{2}{*}{ No. functioning failures } & $-0.203^{\star \star \star}$ & $-0.231^{\star \star \star}$ & $-0.169^{\star \star \star}$ & $-0.144^{\text {*ᄎ }}$ \\
\hline & $(0.050)$ & $(0.012)$ & $(0.044)$ & $(0.012)$ \\
\hline \multirow[t]{2}{*}{ Deprivation } & 0.017 & & $0.053^{\star}$ & \\
\hline & $(0.034)$ & & $(0.031)$ & \\
\hline \multirow[t]{2}{*}{ Satisfaction } & $0.037^{\star}$ & & 0.017 & \\
\hline & $(0.021)$ & & $(0.019)$ & \\
\hline \multirow[t]{2}{*}{ Alienation } & & $0.028^{\star \star}$ & & $0.027^{\star *}$ \\
\hline & & $(0.012)$ & & $(0.012)$ \\
\hline \multirow[t]{2}{*}{ Gini } & 0.100 & 0.097 & $0.128^{\star}$ & $0.130^{\star}$ \\
\hline & $(0.076)$ & $(0.076)$ & $(0.074)$ & $(0.074)$ \\
\hline \multirow[t]{2}{*}{ Age } & $-0.013^{\star \star \star}$ & $-0.013^{\star \star \star}$ & $-0.011^{\star \star \star}$ & $-0.011^{\star \star \star}$ \\
\hline & $(0.002)$ & $(0.002)$ & $(0.002)$ & $(0.002)$ \\
\hline \multirow[t]{2}{*}{ Age-squared/100 } & $0.012^{\star \star \star}$ & $0.012^{\star \star \star}$ & $0.008^{\star \star \star}$ & $0.008^{* \star \star}$ \\
\hline & $(0.002)$ & $(0.002)$ & $(0.002)$ & $(0.002)$ \\
\hline \multirow[t]{2}{*}{ Female } & 0.002 & 0.002 & -0.004 & -0.003 \\
\hline & $(0.011)$ & $(0.011)$ & $(0.011)$ & $(0.011)$ \\
\hline \multirow[t]{2}{*}{ At most secondary education } & $0.057^{\star \star \star}$ & $0.056^{\star \star \star}$ & $0.033^{\star}$ & $0.034^{*}$ \\
\hline & $(0.017)$ & $(0.017)$ & $(0.020)$ & $(0.020)$ \\
\hline \multirow[t]{2}{*}{ At least post-secondary education } & $0.206^{\star \star \star}$ & $0.206^{\star \star \star}$ & $0.074^{\star \star \star}$ & $0.074^{\star \star \star}$ \\
\hline & $(0.021)$ & $(0.021)$ & $(0.025)$ & $(0.025)$ \\
\hline \multirow[t]{2}{*}{ Employed } & $0.040^{\star *}$ & $0.039^{* \star}$ & $0.058^{* \star *}$ & $0.058^{* \star *}$ \\
\hline & $(0.019)$ & $(0.019)$ & $(0.021)$ & $(0.021)$ \\
\hline \multirow[t]{2}{*}{ Unemployed } & $-0.108^{\star \star \star}$ & $-0.109^{\star * \star}$ & 0.009 & 0.009 \\
\hline & $(0.017)$ & $(0.017)$ & $(0.019)$ & $(0.019)$ \\
\hline \multirow[t]{2}{*}{ Urban } & 0.019 & 0.015 & $-0.055^{\star \star \star}$ & $-0.052^{* \star \star}$ \\
\hline & $(0.019)$ & $(0.018)$ & $(0.020)$ & $(0.019)$ \\
\hline Observations & 43,865 & 43,865 & 38,514 & 38,514 \\
\hline Adjusted $\mathrm{R}^{2}$ & 0.140 & 0.140 & 0.135 & 0.135 \\
\hline
\end{tabular}

Notes: clustered standard errors are in parentheses. Wave and country fixed effects are included but the coefficients are not reported. ${ }^{*} p<0.1,{ }^{\star \star} p<0.05,{ }^{* \star} p<0.01$.

Source: Authors' calculations, based on data from the Afrobarometer. 
Table A7: Economic conditions and inequality: OLS results in the Asianbarometer--all controls

\begin{tabular}{|c|c|c|c|c|}
\hline & \multicolumn{2}{|c|}{ Present } & \multicolumn{2}{|c|}{ Future } \\
\hline & (1) & (2) & (3) & (4) \\
\hline \multirow[t]{2}{*}{ No. functioning failures } & -0.002 & $-0.173^{\star \star \star}$ & 0.075 & $-0.053^{\star \star \star \star ~}$ \\
\hline & $(0.068)$ & $(0.027)$ & $(0.054)$ & $(0.012)$ \\
\hline \multirow[t]{2}{*}{ Deprivation } & $-0.098^{* \star}$ & & $-0.064^{*}$ & \\
\hline & $(0.039)$ & & $(0.032)$ & \\
\hline \multirow[t]{2}{*}{ Satisfaction } & 0.034 & & 0.036 & \\
\hline & $(0.029)$ & & $(0.022)$ & \\
\hline \multirow[t]{2}{*}{ Alienation } & & -0.027 & & -0.012 \\
\hline & & $(0.017)$ & & $(0.009)$ \\
\hline \multirow[t]{2}{*}{ Gini } & $-0.064^{\star \star \star}$ & $-0.067^{\star \star}$ & $-0.038^{\star \star}$ & -0.040 \\
\hline & $(0.013)$ & $(0.026)$ & $(0.015)$ & $(0.026)$ \\
\hline \multirow[t]{2}{*}{ Age } & $-0.029^{\star \star \star}$ & $-0.029^{\star \star \star}$ & $-0.018^{\star \star \star}$ & $0.010^{\star \star \star}$ \\
\hline & $(0.006)$ & $(0.006)$ & $(0.004)$ & $(0.003)$ \\
\hline \multirow[t]{2}{*}{ Age-squared/100 } & $0.028^{\star \star \star}$ & $0.028^{\star \star \star}$ & $0.010^{\star \star \star}$ & -0.001 \\
\hline & $(0.006)$ & $(0.006)$ & $(0.003)$ & $(0.016)$ \\
\hline \multirow[t]{2}{*}{ Female } & -0.004 & -0.003 & -0.002 & -0.002 \\
\hline & $(0.022)$ & $(0.022)$ & $(0.018)$ & $(0.018)$ \\
\hline \multirow[t]{2}{*}{ At most secondary education } & 0.019 & 0.021 & 0.033 & 0.035 \\
\hline & $(0.023)$ & $(0.023)$ & $(0.034)$ & $(0.034)$ \\
\hline \multirow[t]{2}{*}{ At least post-secondary education } & $0.120^{\star \star \star}$ & $0.122^{\star \star \star}$ & $0.067^{\star}$ & $0.069^{*}$ \\
\hline & $(0.030)$ & $(0.031)$ & $(0.036)$ & $(0.036)$ \\
\hline \multirow[t]{2}{*}{ Employed } & 0.010 & 0.011 & 0.015 & 0.015 \\
\hline & $(0.033)$ & $(0.033)$ & $(0.019)$ & $(0.019)$ \\
\hline \multirow[t]{2}{*}{ Unemployed } & $-0.139^{\star \star}$ & $-0.137^{\star \star}$ & $0.063^{\star \star \star}$ & $0.064^{\star \star \star}$ \\
\hline & $(0.052)$ & $(0.052)$ & $(0.020)$ & $(0.020)$ \\
\hline \multirow[t]{2}{*}{ Urban } & -0.079 & -0.082 & -0.015 & -0.018 \\
\hline & $(0.051)$ & $(0.051)$ & $(0.024)$ & $(0.024)$ \\
\hline Observations & 13,542 & 13,542 & 13,542 & 13,542 \\
\hline Adjusted $\mathrm{R}^{2}$ & 0.110 & 0.110 & 0.240 & 0.240 \\
\hline
\end{tabular}

Notes: clustered standard errors are in parentheses. Wave and country fixed effects are included but the coefficients are not reported. ${ }^{*} p<0.1,{ }^{\star \star} p<0.05,{ }^{* \star} p<0.01$.

Source: Authors' calculations, based on data from the Asianbarometer. 
Table A8: Economic conditions and inequality: OLS results in the Latinobarometer-all controls

\begin{tabular}{|c|c|c|c|c|}
\hline & \multicolumn{2}{|c|}{ Present } & \multicolumn{2}{|c|}{ Future } \\
\hline & $(1)$ & $(2)$ & (3) & (4) \\
\hline \multirow[t]{2}{*}{ No. functioning failures } & $-0.144^{\star \star \star}$ & $-0.165^{\star \star \star}$ & $-0.082^{\star \star \star}$ & $-0.068^{\star \star \star}$ \\
\hline & $(0.022)$ & $(0.009)$ & $(0.021)$ & $(0.007)$ \\
\hline \multirow[t]{2}{*}{ Deprivation } & 0.002 & & $0.022^{\star \star}$ & \\
\hline & $(0.011)$ & & $(0.009)$ & \\
\hline \multirow[t]{2}{*}{ Satisfaction } & $0.024^{\star \star}$ & & 0.006 & \\
\hline & $(0.012)$ & & $(0.011)$ & \\
\hline \multirow[t]{2}{*}{ Alienation } & & $0.010^{\star \star}$ & & $0.011^{\star \star \star}$ \\
\hline & & $(0.005)$ & & $(0.004)$ \\
\hline \multirow[t]{2}{*}{ Gini } & -0.035 & -0.035 & $0.138^{\star \star \star}$ & $0.137^{\star \star \star}$ \\
\hline & $(0.048)$ & $(0.048)$ & $(0.046)$ & $(0.046)$ \\
\hline \multirow[t]{2}{*}{ Age } & $-0.023^{\star \star \star}$ & $-0.023^{\star \star \star}$ & $-0.017^{\star \star \star}$ & $-0.017^{\star \star \star}$ \\
\hline & $(0.001)$ & $(0.001)$ & $(0.001)$ & $(0.001)$ \\
\hline \multirow[t]{2}{*}{ Age-squared/100 } & $0.019^{\star \star \star}$ & $0.019^{\star \star \star}$ & $0.010^{\star \star \star}$ & $0.010^{\star \star \star}$ \\
\hline & $(0.001)$ & $(0.001)$ & $(0.001)$ & $(0.001)$ \\
\hline \multirow[t]{2}{*}{ Female } & $-0.031^{\star \star \star}$ & $-0.031^{\star \star \star}$ & -0.006 & -0.006 \\
\hline & $(0.007)$ & $(0.007)$ & $(0.007)$ & $(0.007)$ \\
\hline \multirow[t]{2}{*}{ At most secondary education } & $0.058^{\star \star \star}$ & $0.057^{\star \star \star}$ & $0.052^{\star \star \star}$ & $0.053^{\star \star \star}$ \\
\hline & $(0.009)$ & $(0.009)$ & $(0.010)$ & $(0.010)$ \\
\hline \multirow[t]{2}{*}{ At least post-secondary education } & $0.117^{\star \star \star}$ & $0.117^{\star \star \star}$ & $0.025^{\star}$ & $0.025^{\star}$ \\
\hline & $(0.015)$ & $(0.015)$ & $(0.014)$ & $(0.014)$ \\
\hline \multirow[t]{2}{*}{ Employed } & $0.012^{*}$ & $0.012^{*}$ & $0.020^{* *}$ & $0.020^{\star \star}$ \\
\hline & $(0.007)$ & $(0.007)$ & $(0.008)$ & $(0.008)$ \\
\hline \multirow[t]{2}{*}{ Unemployed } & $-0.204^{\star \star \star}$ & $-0.206^{\star \star \star}$ & -0.010 & -0.010 \\
\hline & $(0.015)$ & $(0.016)$ & $(0.013)$ & $(0.013)$ \\
\hline Observations & 168,279 & 168,279 & 135,216 & 135,216 \\
\hline Adjusted $\mathrm{R}^{2}$ & 0.135 & 0.135 & 0.077 & 0.077 \\
\hline
\end{tabular}

Notes: clustered standard errors are in parentheses. Wave and country fixed effects are included but the coefficients are not reported. ${ }^{\star} p<0.1,{ }^{\star \star} p<0.05,{ }^{\star \star *} p<0.01$.

Source: Authors' calculations, based on data from the Latinobarometer. 
Table A9: Economic conditions and inequality: OLS results in the Eurobarometer-all controls

\begin{tabular}{|c|c|c|c|c|}
\hline & \multicolumn{2}{|c|}{ Present } & \multicolumn{2}{|c|}{ Future } \\
\hline & $(1)$ & $(2)$ & (3) & (4) \\
\hline \multirow[t]{2}{*}{ No. functioning failures } & 0.019 & $-0.202^{\star \star \star}$ & 0.143 & $-0.074^{\star \star \star}$ \\
\hline & $(0.095)$ & $(0.006)$ & $(0.136)$ & $(0.008)$ \\
\hline \multirow[t]{2}{*}{ Deprivation } & $-0.099^{*}$ & & -0.100 & \\
\hline & $(0.052)$ & & $(0.072)$ & \\
\hline \multirow[t]{2}{*}{ Satisfaction } & $0.115^{\star \star \star}$ & & $0.110^{\star}$ & \\
\hline & $(0.041)$ & & $(0.062)$ & \\
\hline \multirow[t]{2}{*}{ Alienation } & & $0.011^{\star \star}$ & & $0.009^{* *}$ \\
\hline & & $(0.005)$ & & $(0.004)$ \\
\hline \multirow[t]{2}{*}{ Gini } & 0.035 & 0.020 & 0.061 & 0.048 \\
\hline & $(0.035)$ & $(0.034)$ & $(0.040)$ & $(0.036)$ \\
\hline \multirow[t]{2}{*}{ Age } & $-0.032^{\star \star \star}$ & $-0.032^{\star \star \star}$ & $-0.031^{\star \star \star}$ & $-0.031^{\star \star *}$ \\
\hline & $(0.002)$ & $(0.002)$ & $(0.002)$ & $(0.002)$ \\
\hline \multirow[t]{2}{*}{ Age-squared/100 } & $0.037^{\star \star \star}$ & $0.037^{\star \star \star}$ & $0.022^{\star \star \star}$ & $0.022^{\star \star \star}$ \\
\hline & $(0.001)$ & $(0.001)$ & $(0.001)$ & $(0.001)$ \\
\hline \multirow[t]{2}{*}{ Female } & $-0.024^{\star \star \star}$ & $-0.024^{\star \star \star}$ & $-0.023^{\text {kᄎ }}$ & $-0.023^{\text {kᄎ }}$ \\
\hline & $(0.006)$ & $(0.006)$ & $(0.007)$ & $(0.007)$ \\
\hline \multirow[t]{2}{*}{ At most secondary education } & $0.145^{\star \star \star}$ & $0.144^{\star \star \star}$ & $0.046^{\star \star \star}$ & $0.045^{\star \star \star}$ \\
\hline & $(0.009)$ & $(0.009)$ & $(0.008)$ & $(0.008)$ \\
\hline \multirow[t]{2}{*}{ At least post-secondary education } & $0.263^{\star \star \star}$ & $0.263^{\star \star \star}$ & $0.108^{\star \star \star}$ & $0.108^{\star \star \star}$ \\
\hline & $(0.012)$ & $(0.012)$ & $(0.011)$ & $(0.011)$ \\
\hline \multirow[t]{2}{*}{ Employed } & $0.173^{* \star *}$ & $0.173^{* \star *}$ & $0.043^{* \star *}$ & $0.043^{* * *}$ \\
\hline & $(0.012)$ & $(0.012)$ & $(0.010)$ & $(0.010)$ \\
\hline \multirow[t]{2}{*}{ Unemployed } & $-0.480^{\star \star \star}$ & $-0.480^{\star * \star}$ & -0.009 & -0.009 \\
\hline & $(0.019)$ & $(0.019)$ & $(0.020)$ & $(0.020)$ \\
\hline Observations & 100,379 & 100,379 & 97,778 & 97,778 \\
\hline Adjusted $\mathrm{R}^{2}$ & 0.305 & 0.305 & 0.082 & 0.082 \\
\hline
\end{tabular}

Notes: clustered standard errors are in parentheses. Wave and country fixed effects are included but the coefficients are not reported. ${ }^{*} p<0.1,{ }^{\star \star} p<0.05,{ }^{\star \star *} p<0.01$.

Source: Authors' calculations, based on data from the Eurobarometer. 